\title{
Lipid dysfunction and pathogenesis of multiple system atrophy
}

Jonathan M Bleasel ${ }^{1,2}$, Joanna H Wong ${ }^{1,2}$, Glenda M Halliday ${ }^{1,2}$ and Woojin Scott Kim ${ }^{1,2^{*}}$

\begin{abstract}
Multiple system atrophy (MSA) is a progressive neurodegenerative disease characterized by the accumulation of a-synuclein protein in the cytoplasm of oligodendrocytes, the myelin-producing support cells of the central nervous system (CNS). The brain is the most lipid-rich organ in the body and disordered metabolism of various lipid constituents is increasingly recognized as an important factor in the pathogenesis of several neurodegenerative diseases. a-Synuclein is a $17 \mathrm{kDa}$ protein with a close association to lipid membranes and biosynthetic processes in the CNS, yet its precise function is a matter of speculation, particularly in oligodendrocytes. a-Synuclein aggregation in neurons is a well-characterized feature of Parkinson's disease and dementia with Lewy bodies. Epidemiological evidence and in vitro studies of a-synuclein molecular dynamics suggest that disordered lipid homeostasis may play a role in the pathogenesis of a-synuclein aggregation. However, MSA is distinct from other a-synucleinopathies in a number of respects, not least the disparate cellular focus of a-synuclein pathology. The recent identification of causal mutations and polymorphisms in COQ2, a gene encoding a biosynthetic enzyme for the production of the lipid-soluble electron carrier coenzyme $\mathrm{Q}_{10}$ (ubiquinone), puts membrane transporters as central to MSA pathogenesis, although how such transporters are involved in the early myelin degeneration observed in MSA remains unclear. The purpose of this review is to bring together available evidence to explore the potential role of membrane transporters and lipid dyshomeostasis in the pathogenesis of a-synuclein aggregation in MSA. We hypothesize that dysregulation of the specialized lipid metabolism involved in myelin synthesis and maintenance by oligodendrocytes underlies the unique neuropathology of MSA.
\end{abstract}

Keywords: Multiple system atrophy, Lipid, a-synuclein, Oligodendrocyte, COQ2, ABCA8

\section{Introduction}

Multiple system atrophy (MSA) is a progressive neurodegenerative disease characterized by the clinical triad of parkinsonism, cerebellar ataxia and autonomic failure. The distribution of pathology classically encompasses three functional systems in the central nervous system (CNS); the striatonigral system, olivopontocerebellar system and autonomic nuclei of the brainstem and spinal cord $[1,2]$. MSA typically affects individuals in the sixth decade of life or later [3] with a mean survival of approximately 9 years $[4,5]$. The annual incidence in the age group 50-99 years has been estimated at 3 cases per 100,000 person years $[6,7]$. While the general consensus is that MSA is a highly sporadic disease, emerging evidence has suggested rare

\footnotetext{
* Correspondence: w.kim@unsw.edu.au

'Neuroscience Research Australia, Barker St, Randwick, Sydney NSW 2031, Australia

${ }^{2}$ School of Medical Sciences, University of New South Wales, Sydney NSW
} 2052, Australia genetic variants increase susceptibility, although this appears to be dependent on the geographical distribution of sample patients [8-11]. Furthermore, albeit scant, evidence suggesting environmental risk factors similarly increasing susceptibility has also been reported [12-16].

The pathological hallmark of MSA is the appearance of glial cytoplasmic inclusions (GCIs) in oligodendrocytes (Figure 1), the myelin producing support cells of the central nervous system (CNS). GCIs comprise insoluble proteinaceous filaments composed chiefly of $\alpha$-synuclein ( $\alpha$-syn) [17]. $\alpha$-Syn is a $17-\mathrm{kDa}$ protein encoded by the SNCA gene at the cytogenetic location 4q22.1. It is predominantly expressed in neurons where it appears to localize in the synaptic terminal and play a role in vesicle transport and turnover [18-20]. Deposits of insoluble $\alpha$-syn also occur in neurons in Parkinson's disease (PD) and dementia with Lewy bodies (DLB), although the filament size and morphology in these 
A

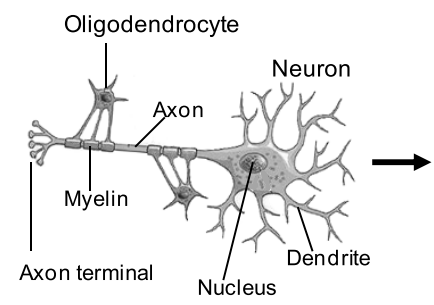

B

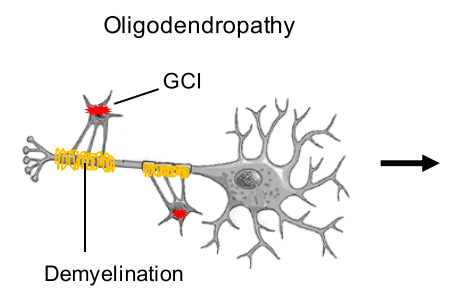

C

Neurodegeneration

Loss of structure \& function Cell death

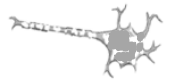

Figure $1 \mathrm{~A}$ putative model of oligodendrocyte dysfunction in multiple system atrophy. (A) Normal oligodendrocytes with myelin covering the axon of a neuron. (B) Formation of glial cytoplasmic inclusions (GCls), composed of aggregated a-synuclein, and demyelination. (C) Demyelination is followed by neurodegeneration and cell death.

inclusions differ somewhat from that of GCIs [21]. The causes of $\alpha$-syn aggregation and the reason for the unique oligodendrocyte focus of pathology in MSA remain poorly understood. However, in line with advances in understanding of other neurodegenerative proteinopathies, including Alzheimer's disease [22,23], the metabolism of lipids in the brain is emerging as an important focus in the study of proteinopathies and $\alpha$-syn pathophysiology.

For $\alpha$-syn, such lines of evidence stem from studies which demonstrate that $\alpha$-syn readily binds to lipid droplets and phospholipid bilayers in vitro, whereby lipid membrane association induces folding of the protein from its unfolded cytosolic state to a stable $\alpha$-helical conformation [19]. In vivo, membrane association and diverse effects on lipid metabolism appear to be important components of the physiological function of $\alpha$-syn in the CNS. It follows that disruption of lipid metabolism and lipid-membrane composition and integrity could play an important role in the pathogenesis of $\alpha$-synucleinopathies. However, the specific role of oligodendrocyte membrane transport and lipid metabolism in MSA remains to be clearly elucidated.

The purpose of this review is to explore the significance of brain lipid metabolism in MSA pathogenesis. We will firstly discuss oligodendrocyte-specific processes, specifically myelin formation, which may underlie the unique glial focus of MSA pathology. The relevance of lipid membranes and metabolism to the normal physiology and dysfunction of $\alpha$-syn will then be explored. Finally, epidemiological evidence linking membrane transport and lipid dyshomeostasis to MSA will be discussed.

\section{Review}

\section{Oligodendrocyte-specific pathology}

In an effort to distinguish processes specific to MSA pathogenesis, the physiology and maintenance of myelin presents a natural focus, given the primary lesion in MSA occurs within oligodendrocytes. Myelin in cross section is a spiral structure constituted by multiple layers of a specialized extension of the oligodendrocyte plasma membrane that wraps around axons (reviewed in [24]). The composition of myelin is characterized by high proportions of cholesterol and glycosphingolipids, which are arranged in a highly ordered structure with associated structural and signaling proteins. Hence, this highlights the importance in maintaining appropriate lipid concentrations, as they are crucial for the proper formation of myelin.

Myelin is traditionally known to function as an electrical insulator for axons to facilitate the rapid propagation of action potentials. However, Ravera and colleagues [25] have recently demonstrated that similar to mitochondria, isolated myelin vesicles possess the capacity to undergo oxidative phosphorylation to generate ATP for axons. Hence, myelin may hold additional roles that contribute towards axonal survivability. Therefore, defects in myelin arising from lipid dyshomeostasis could potentially perturb the survivability of axons to in turn cause neurodegeneration as a contributor towards MSA pathogenesis. The mechanism by which axonal degeneration induces neurodegeneration is discussed in a review by Wang et al. [26], although another recent study reported an absence of axonal degeneration following chronic dysmyelination in the Long-Evans shaker rat [27]. These rats are characterized by myelination abnormalities resulting from a mutation in the gene that encodes myelin basic protein [27]. While such conflicting findings are possibly the result of varying experimental conditions, clarification of the relationship between myelin loss, axonal degeneration and neurodegeneration is required.

Despite the conflicting findings on the link between myelin integrity, axonal survivability and neurodegeneration, the disruption of myelin has been proposed to be an early process in the pathogenesis of MSA by Song and colleagues [28]. More specifically, the authors observed abnormal subcellular relocalization of myelin-associated proteins, which appeared to precede $\alpha$-syn aggregation into GCIs. The earliest changes observed included the relocalization of p $25 \alpha$ from the myelin sheath to the cell body of oligodendrocytes, which was presumed to induce abnormal expansion of the cell body. Moreover, similar relocalization patterns were observed with myelin basic protein whilst 
also demonstrating increased degradation and accumulation in the expanded soma of affected oligodendrocytes. A previous study of myelin changes in MSA also noted that proteolysis of myelin basic protein was an early marker of oligodendrocyte pathology in affected brain areas and sometimes preceded the appearance of GCIs [29]. Substantiating the relevance of these observations to later $\alpha$-syn aggregation in MSA, p25 $\alpha$ co-localizes with $\alpha$-syn in GCIs and is a potent inducer of $\alpha$-syn aggregation in vitro [30-32]. Thus a disruption of myelin synthesis and maintenance in oligodendrocytes could represent the primary disturbance in MSA. A possible source of this disturbance could lie in the synthesis and handling of key myelin lipids by oligodendrocytes. The consequent alteration in myelin membrane composition would then be likely to impact upon membrane association with $\alpha$-syn as a precedent to $\alpha$-syn aggregation. In addition, with its putative role in diverse lipid biosynthetic pathways, $\alpha$-syn expression may be governed by feedback mechanisms operating in response to myelin lipid abnormalities.

\section{a-Synuclein pathology \\ a-Synuclein oligomers are key cytotoxic species in a-synucleinopathies}

The $\alpha$-syn protein contains a highly hydrophobic 12 -amino acid domain at its center (71-VTGVTAVAQKTV-82), which appears to be essential for fibrilization of the protein [33]. Deletion or disruption of this domain through the addition of a charged amino acid abrogates the ability of $\alpha$-syn to form amyloid fibrils [33]. Insoluble aggregates of $\alpha$-syn with this 12 amino acid stretch at their core [33] are the pathological hallmarks of PD/DLB and MSA in neurons and oligodendrocytes respectively. However, a significant body of evidence suggests that mature $\alpha$-syn fibrils are not required for cytotoxicity in these disease processes. Instead, early misfolded forms of $\alpha$-syn, possibly dimers or small oligomers, are proposed to be the primary toxic species [34]. Consistent with this hypothesis, investigations of $\alpha$-syn mutants linked to familial forms of PD (A30P and A53T) have found that both forms undergo self-association to form soluble oligomers more rapidly than wild-type protein, however only A53T demonstrates faster formation of fibrils $[35,36]$. Underlying their toxicity, $\alpha$-syn oligomers assume annular pore-forming configurations which may be capable of causing inappropriate permeabilization of cellular membranes [37]. Subsequent aggregation into visible fibrils may even serve as protective sequestration of this toxic species $[34,38]$.

\section{Formation of a-synuclein oligomers at the lipid membrane surface}

As highlighted above, under normal conditions $\alpha$-syn exists as randomly structured and natively unfolded monomer within the cytoplasm. However, at the membrane surface in the presence of lipids $\alpha$-syn adopts a dramatic change in structure to a folded $\alpha$-helical secondary structure [39]. A number of studies have suggested that the helix-rich membrane bound form of $\alpha$-syn plays a crucial role in initiating the pathological aggregation of the protein. Accelerated $\alpha$-syn aggregation has been observed as a result of $\alpha$-syn exposure to long chain polyunsaturated fatty acids [40] and with increased binding to membranes and lipid droplets within cells [41]. In a study of isolated brain fractionates of $\alpha$-syn, Lee and colleagues [42] observed progressive aggregation of the protein in the membrane fraction but no aggregation in the cytosolic fraction after 3 days. Moreover, addition of cytosolic $\alpha$-syn to the membrane fraction accelerated aggregation, suggesting that initial self-association at the membrane may seed accumulation of the more abundant cytosolic form of $\alpha$-syn.

\section{Lipid membrane composition influences a-synuclein association}

Additional studies of lipid membrane composition and structure shed further light on the mechanics of $\alpha$-syn membrane association and dysfunction. Fortin and colleagues [18] observed that $\alpha$-syn binds preferentially to lipid raft microdomains in biological membranes. Lipid raft microdomains have been shown to be essential for oligodendrocyte survival signaling by providing a favorable environment for growth factor-mediated integrin activation [43]. Lipid rafts are highly dynamic sterol- and sphingolipidenriched structures, which compartmentalize many cellular processes occurring in biological membranes [44,45]. Quantitative manipulation of constituent lipid species leads to disorganization of lipid raft microdomains and dissociation of proteins bound to the lipid rafts $[46,47]$. Fortin and colleagues [18] noted that cholesterol extraction disrupted lipid rafts and dramatically reduced $\alpha$-syn association in vitro. Conversely, Cole and colleagues [41] loaded HeLa cells expressing wild-type $\alpha$-syn with free fatty acid and found significant increases in $\alpha$-syn association with membranes and triglyceride-rich lipid droplets. Thus it appears that the dynamics of intracellular $\alpha$-syn association are highly responsive to manipulation of lipid homeostasis and membrane composition. A number of studies have shown that the A30P $\alpha$-syn mutant associated with familial PD displays defective binding to lipid membranes, while the A53T mutant shows no such difference compared to wild-type protein $[18,48,49]$. Although there are no known causative $\alpha$-syn mutations in MSA, variants of the SNCA gene have been identified to be associated with an increased risk for MSA [11,50]. 


\section{a-Synuclein plays a role in lipid-mediated signaling and synaptic vesicle function}

$\alpha$-Syn is expressed primarily by neurons, where it is especially enriched at their presynaptic terminals $[18,51,52] . \alpha$-Syn is described as a natively unfolded protein since it forms a disordered 'random coil' configuration in its cytosolic state [53]. The association of $\alpha$-syn with lipid membranes is well established by in vitro methods [19,39]. Lipid association, moreover, induces folding of the protein to a stable $\alpha$-helical conformation $[19,39,54]$. However, the significance of these observations for the physiological function of the protein in vivo remains incompletely understood.

A study of $\alpha$-syn structure found high homology of sequences at the $\mathrm{C}$ and $\mathrm{N}$ terminals to characteristic motifs of the fatty acid binding protein (FABP) family, suggesting $\alpha$-syn may play a role in intracellular fatty acid transport [55]. However, subsequent findings have suggested a more nuanced relationship to lipid membranes and cellular lipid metabolism. The propensity of $\alpha$-syn to bind and stabilize small lipid vesicles [19,41] and the subcellular localization of the protein at the presynaptic terminal in neurons $[18,51,52]$ are suggestive of a role in synaptic transmission. Indeed, transgenic mice lacking $\alpha$-syn $\left(\alpha-\right.$ syn $\left.^{-1-}\right)$ show deficits in nigrostriatal dopaminergic neurotransmission [20,56]. On a sub-cellular level, Cabin and colleagues [56] found that $\alpha$-syn ${ }^{-1-}$ mice have a $50 \%$ reduction in size of undocked synaptic vesicle pool and synaptic vesicle depletion after high-frequency stimulation.

The mechanism of this influence on vesicle function and turnover may rely on the interaction of $\alpha$-syn with phospholipase enzymes and associated lipid-mediated signal transduction. $\alpha$-Syn binds to and inhibits the activity of phospholipase D (PLD) [57,58] - an enzyme involved in lipid-mediated signaling cascades responsible for regulating functions including cytoskeletal rearrangement and endocytosis [59]. PLD inhibition appears to be required for synaptic vesicle fusion with the target membrane and may regulate synaptic vesicle recycling. This is consistent with the results of Cabin and colleagues [56] who showed a reduction in the synaptic vesicle pool in $\alpha$-syn ${ }^{-/-}$mice. A further role in intracellular signaling was suggested by Narayanan and colleagues [60], who found that $\alpha$-syn also binds to phospholipase $C \beta$ (PLC $\beta$ ), which is a G-protein coupled enzyme in the dopamine-signaling pathway that exerts downstream effects through calcium signaling by hydrolyzing phosphatidylionositol. This binding interaction was found to inhibit the catalytic activity of PLC $\beta$ by $50 \%$. Later studies have suggested $\alpha$-syn also prevents the degradation of a specific type of PLC $\beta$ - PLC $\beta 1$, to in turn promote calcium signaling [61]. Interestingly, A53T mutations in $\alpha$-syn that are linked to familial PD are also associated with weaker binding to PLC $\beta$ [60]. Hence, this could potentially serve as a mechanism by which $\alpha$-syn perturbs downstream effects of PLC $\beta$ as a consequence of reduced activation of lipid signaling pathways.

\section{a-Synuclein exerts a wider influence on lipid metabolism in the brain}

The in vitro findings summarized above are largely specific for neuronal physiology, which is characteristic of the bulk of $\alpha$-syn research. However, the primary oligodendrocyte pathology exhibited in MSA demands a broader consideration of the function of this protein in the brain. A research team headed by E.J. Murphy of the Ohio State University has published a number of important studies suggesting a wider role for $\alpha$-syn in brain lipid metabolism. This includes a study demonstrating that astrocytes cultured from $\alpha$-syn gene-ablated mice have significantly disrupted uptake of the fatty acids palmitate and arachidonic acid with increased trafficking to the neutral lipid pool and decreased trafficking to phospholipids [62]. Again in whole brains of $\alpha-\mathrm{syn}^{-/-}$mice, uptake of palmitic acid was reduced by $35 \%$ and there was significantly altered incorporation into a number of phospholipid classes [63]. It is proposed that these effects on fatty acid uptake and trafficking are independent of any function as a FABP on account of the failure to demonstrate any binding of $\alpha$-syn to oleic or palmitic acid using titration microalorimetry [63]. The mechanism may instead relate to $\alpha$-syn regulation of acyl-CoA synthase activity, which mediates incorporation of palmitate into the acyl-CoA pool from where it is incorporated into individual phospholipids $[63,64]$.

From the same research team, Ellis and colleagues [65] found a significant reduction in the linked complex I/III activity of the electron transport chain in mitochondria of $\alpha$-syn ${ }^{-1-}$ mice. This was apparently mediated by reduced levels and altered fatty acid composition of cardiolipin, an important component of the mitochondrial membrane required for assembly and function of the electron transport chain. Of significance and unlike PD, there is no significant deficit in mitochondrial respiratory chain activity in MSA [66]. However, this may still be of particular relevance to MSA since oxidative stress precipitates MSA neuropathology, as evidenced by the potentiating effects of mitochondrial toxin 3-nitroproprionic acid on clinical deficits and neurodegeneration in transgenic mouse models of the disease [67,68]. While speculative, in MSA dysfunction of myelin respiratory chain activity may be affected due to alterations in myelin lipid homeostasis.

In summary, $\alpha$-syn appears to have diverse roles in brain lipid metabolism, including lipid-mediated signaling pathways and fatty acid trafficking to key phospholipid pools integral to the structure and function of biological membranes. These functions may be integral to an understanding of the reciprocal influences of lipid 
membrane composition on pathological $\alpha$-syn aggregation as discussed below.

\section{Pathophysiology mechanisms of lipids in MSA Shifts in membrane-associated a-synuclein observed in MSA brains}

The in vitro evidence for the pathogenicity of membrane bound forms of $\alpha$-syn has been substantiated by several studies of human brain tissue fractionates from individuals affected by MSA and other $\alpha$-synucleinopathies. Casecontrol analyses of $\alpha$-syn solubility in human brain tissue have shown increases in sodium dodecyl sulfate (SDS)-soluble 'membrane-associated' $\alpha$-syn in disease affected regions of MSA brains with concomitant decreases or no change in the buffer-soluble cytosolic fraction [69-74]. These observations lend support to the hypothesis that a solubility shift from the cytosolic to membrane compartment may be a fundamental process in $\alpha$-syn pathology in $\alpha$-synucleinopathies. Furthermore, one detailed comparative study of PD and MSA brain tissue [74] revealed distinct patterns of $\alpha$-syn solubility between the disease groups. Along with the expected wider regional involvement in MSA, there was also much greater quantitative accumulation of membrane-associated $\alpha$-syn in the MSA substantia nigra compared to PD. The extent of membrane associated $\alpha$-syn accumulation also appeared to positively correlate with neurodegeneration in MSA (especially in the striatum) but not in PD. Hence, these disparities highlight that unique pathophysiologies of $\alpha$-syn dysfunction are likely to operate in MSA and PD, which would explain the fundamentally different cellular focus of pathology in each disease.

\section{Association of COQ2 with pathogenesis of MSA}

A recent collaborative study that combined linkage analysis with whole-genome sequencing of a post-mortem sample from a member of a multiplex family with a history of MSA, has provided the first piece of evidence linking COQ2 to MSA [10]. More specifically, the common V343A variant in the COQ2 gene was found to be associated with an increased risk of sporadic MSA in Japanese populations [10]. The COQ2 gene encodes a biosynthetic enzyme in the production of coenzyme $\mathrm{Q}_{10}$ (also known as ubiquinone) [75]. Coenzyme $\mathrm{Q}_{10}$ is a lipid-soluble compound that acts as a powerful antioxidant and the main electron acceptor in the electron transport respiratory chain. It is present in membranes of all cells and tissues, and is vital for the intracellular transport of electrons from complex I and II to complex III in the respiratory chain [76]. It is of interest that the $\alpha$-syn ${ }^{-1-}$ mice have dysfunction at this site in the respiratory chain [65]. While generally concentrated within mitochondria, myelin also possesses the capacity to undergo oxidative phosphorylation and generate ATP for axons through functional electron transport chains within myelin membranes [25], and therefore requires coenzyme $\mathrm{Q}_{10}$ to perform this function. By measuring the effects of the V343A variant in lymphoblastoid lines, the collaborators demonstrated the variant induced functional impairments in COQ2, which is consistent with the decreased coenzyme $\mathrm{Q}_{10}$ levels in MSA brains in comparison to control [10].

Dysfunction and decreased levels of coenzyme $\mathrm{Q}_{10}$ promotes oxidative stress through an inability to remove free radicals, ultimately facilitating apoptosis-induced cell death $[77,78]$. Thus in the context of MSA, dysfunctional and apoptotic oligodendrocytes as a consequence of altered coenzyme $\mathrm{Q}_{10}$ function could contribute towards an inability to form and maintain myelin, which may impact on the long-term viability of demyelinated axons (see above). Interestingly, deficiencies of coenzyme $\mathrm{Q}_{10}$ appear to manifest with some symptomatic features characteristic of MSA, such as cerebellar ataxia and atrophy $[79,80]$.

According to Fünfschilling and colleagues [81] however, the disruption of oxidative phosphorylation in cultured oligodendrocytes by inhibiting the formation of the mitochondrial complex IV does not impede the ability of oligodendrocytes to myelinate axons. Instead, the authors proposed that oligodendrocytes are capable of compensatory glycolytic activity upon disruption of oxidative phosphorylation, as evidenced by a significantly increased glycolytic rate in affected oligodendrocytes. Therefore, the role of coenzyme $\mathrm{Q}_{10}$ in MSA is unclear and will require further in-depth investigation, although its role in contributing towards oxidative stress remains plausible (discussed below).

\section{ABCA8 - a novel oligodendrocyte lipid transporter}

Besides COQ2, recent investigation of a novel member of the ATP-binding cassette (ABC) transporter family, $\mathrm{ABCA} 8$, has opened the way to a more detailed understanding of myelin formation and pathology. ABC transporters are transmembrane proteins that utilize the energy of adenosine triphosphate (ATP) hydrolysis to carry out certain biological processes $[82,83]$. The A subfamily of $\mathrm{ABC}$ transporters shares a common substrate specificity for lipid species [84] and several members have well characterized associations with human disease including neurodegeneration [85]. ABCA8 has recently been shown to be differentially expressed in multiple regions of adult human brains with significantly higher expression in oligodendrocyte-enriched white matter regions compared to grey matter cortical regions [86]. The expression of ABCA1 (the prototype in A subfamily) was unaltered in white matter regions, suggesting that ABCA8 may have a unique role in the brain white matter (Figure 2). Furthermore, in the same study, 

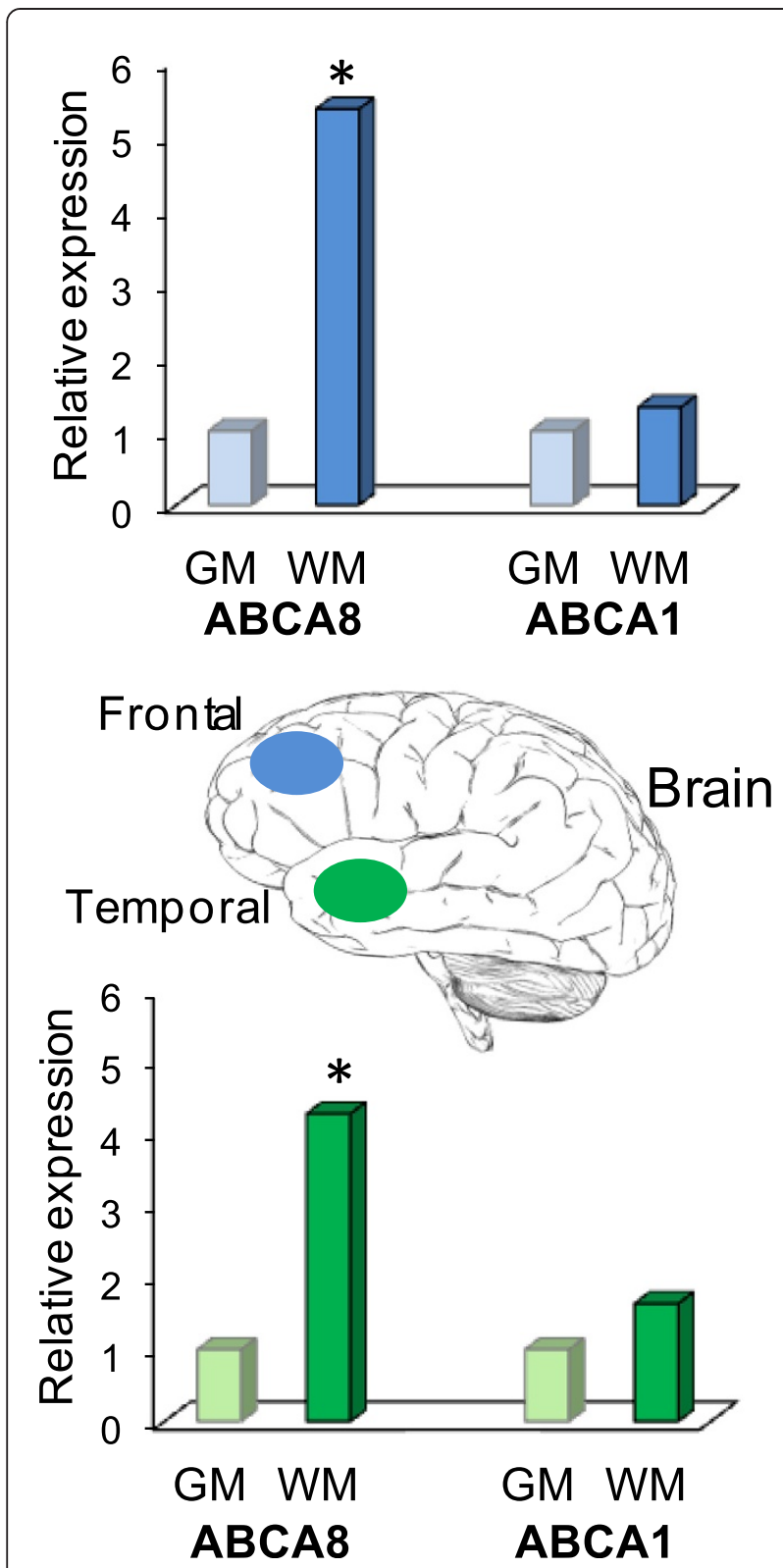

Figure 2 Elevated expression of the lipid transporter $A B C A 8$ in white matter regions of human brain. The expression of $A B C A 8$ and $A B C A 1$ (prototype in A subfamily) was measured in the superior frontal grey matter (GM) and white matter (WM) and inferior temporal GM and WM from six normal adults, comprising of three males and three females, by quantitative PCR; ${ }^{*} p<0.01$ (Student's $t$ test).

quantitative expression analysis in the prefrontal cortex across the human life-span showed increases correlating with age-associated myelination $[87,88]$ and in conjunction with upregulation of the myelinating gene p25 $\alpha$. In vitro, ABCA8 was able to significantly stimulate both sphingomyelin synthase 1 expression and sphingomyelin production in a human oligodendrocyte cell line. Sphingomyelin is an important glycosphingolipid component of the myelin membrane. In sum these results strongly suggest that ABCA8 regulates lipid metabolism in oligodendrocytes and potentially plays a role in myelin formation and maintenance. It is likely that this ATP requiring transporter co-locates with respiratory chain proteins producing ATP within the myelin membrane to perform these roles.

The influence of ABCA8 on sphingomyelin metabolism may have cellular impacts beyond myelin structural integrity. Sphingomyelin is enriched in lipid-raft microdomains where it is thought to be an important mediator of membrane rigidity and permeability [89] and of compartmentalization of raft-associated cellular processes [90]. Sphingomyelin is also part of an important signaling pathway in which it is cleaved by sphingomyelinase to form ceramide which serves as a second messenger for cellular functions including cell cycle progression, proliferation, differentiation and apoptosis (reviewed in [91]). Sphingomyelin accumulation with or without significant sphingomyelinase deficiency are features of Niemann-Pick disease, of which subtypes A, C and D manifest with irreversible neurological damage [92].

Bleasel and colleagues [93] have tested the hypothesis that ABCA8 expression is associated with the disease process of MSA through involvement in the early disruption of myelin processing with subsequent impacts on the function and homeostasis of the key disease proteins $\alpha$-syn and $25 \alpha$. ABCA 8 mRNA expression was significantly increased in MSA brains compared to controls in disease-affected grey matter (putamen and cerebellum) and disease-affected white matter underlying the motor cortex with no significant change in an unaffected region (visual cortex). ABCA 8 and p $25 \alpha$ expression were also positively correlated in disease-affected regions in both MSA and control tissue. These results strongly suggest that the upregulation of ABCA8 is associated at some level with the MSA disease process, possibly in response to reduced ATP production in myelin if COQ2 is involved (discussed above). The positive correlation between ABCA 8 and $\mathrm{p} 25 \alpha$ may substantiate a link between ABCA8 and pre-GCIs disease events in line with the findings of Song and colleagues [28] outlined above. The relocalisation of $\mathrm{p} 25 \alpha$ from the myelin sheath to the cell soma observed in this study was proposed to be part of a wider initial myelin dysfunction in MSA, consistent with a concurrent disruption of the putative myelin lipid transporter ABCA8.

The role of transcriptional upregulation of $\alpha$-syn and other GCI proteins in the pathogenesis of MSA has been a contentious issue. Previous quantitative studies of MSA post-mortem tissue have failed to demonstrate $\alpha$-syn overexpression at the mRNA level [15,94-97]. However it remain possible that small expression changes in oligodendrocytes could be masked by secondary neuronal 
death and dysfunction and more cell-specific expression studies are necessary. Other commentators have suggested that negative feedback mechanisms may secondarily suppress SNCA overexpression in established disease [95]. In an in vitro follow-up to the human tissue analysis cited above [93], overexpression of ABCA8 in cultured MO3.13 oligodendrocytes caused significant increases in expression of $\alpha$-syn and p25 $\alpha$ at the mRNA level. While caution is necessary attributing any causative role to ABCA8 in MSA pathogenesis at this stage, these results lend strong support to the relevance of myelin lipid dysregulation to $\alpha$-syn pathology in oligodendrocytes.

\section{Association of cholesterol (rate-limiting lipid for myelination) and MSA}

\section{Higher serum cholesterol associated with decreased risk of MSA}

In contrast to the numerous investigations of PD cohorts, only two case-control studies have examined the link between serum lipids and MSA. In the first study, Lee and colleagues [98] recruited 142 subjects with probable MSA and 155 age- and gender- matched controls for a cross-sectional analysis. The risk of MSA in the lowest quartile of total cholesterol (TC), low density lipoprotein (LDL) cholesterol and high density lipoprotein (HDL) cholesterol was significantly higher compared to the highest quartile of each. The ORs remained significant for low TC and HDL when adjusting for age, gender, use of cholesterol-lowering drugs, and histories of hypertension, diabetes mellitus, and smoking. The authors considered potential confounders including relative malnutrition with increasing severity of disease and use of a feeding tube, however these factors were not significantly correlated with lipid profiles. The recent second study of MSA in a Chinese population has confirmed the conclusion of the first study [99]. Other evidence linking particular dietary factors to MSA is conflicting however - meat and poultry consumption has been found to have both a positive [100] and negative [13] association to the disease in separate cross-sectional samples.

\section{Correlation to PD evidence}

The suggestion of a link between increased MSA risk and low serum cholesterol is consistent with some observational studies of PD, but the literature is marked by conflicting findings. Two prospective cohort studies have reported an inverse relationship between serum cholesterol and PD risk. de Lau and colleagues [101] reported a decreased risk of PD with increasing total cholesterol and evidence of a dose response relationship, however the association was restricted to women. Using self-reported total cholesterol levels, Simon and colleagues [102] also reported a modest decrease in relative risk with higher total cholesterol levels. Retrospective case-control studies have also reported a higher PD occurrence with lower $\mathrm{TC}$ and triglycerides [103] and with low LDL cholesterol [104]. In conflicting results, one prospective study [105] found an association between high total cholesterol at baseline and increased incidence of PD while another found no association [106]. Similarly, observational studies of dietary fat intake have reported a mix of conflicting associations: increased risk with increased total fat (particularly animal fat) [107-109], decreased risk with increased total fat and poly- and mono-unsaturated fatty acids (FA) [110]; increased risk with lower dietary cholesterol [111] and no association $[112,113]$. However, in a recent meta-analysis, Gudala and colleagues [114] revealed that there were no association between serum cholesterol and risk of PD, suggesting differences in lipid pathophysiology underlying PD and MSA.

\section{Relevance of peripheral cholesterol homeostasis to the CNS}

The mechanism for an increased risk of MSA with low levels of serum cholesterol is not obvious. The brain is the most cholesterol rich organ in the body with more cholesterol in the white matter due to myelin's increased membrane density. Disturbances in cholesterol homeostasis may disrupt cell membranes where $\alpha$-syn appears to exert some of its functions $[101,105]$. However, the fact remains that cholesterol-bearing lipoproteins in the peripheral circulation do not cross the blood brain barrier and most brain cholesterol is synthesized in situ [115]. On the contrary, oxidized cholesterol derivatives can easily diffuse across the blood brain barrier and may provide a mechanism of interaction between central and peripheral cholesterol pools. These derivatives include 24S-hydroxycholesterol, which appears to be involved chiefly in excretion of excess brain-synthesized cholesterol to the periphery [116] while 27-hydroxycholesterol demonstrates a net flux in the opposite direction where it concentrates in the white matter [117]. In further support of this possibility, Bosco and colleagues [118] reported increased levels of locally generated oxidative cholesterol metabolites in the cortices of DLB patients compared to controls, and a pro-aggregating effect of oxysterols on $\alpha$-syn in vitro. The potential influence of peripheral cholesterol dyshomeostasis via 27-hydroxycholesterol is not implicated in the discussion of these findings. Thus the interaction of peripheral and CNS cholesterol homeostasis and its relevance to $\alpha$-syn pathophysiology in vivo remain speculative.

Alternatively, coenzyme $\mathrm{Q}_{10}$ has been proposed to be a neuroprotective factor in PD pathogenesis due to its antioxidant properties $[119,120]$. Thus, since serum cholesterol is the strongest determinant of coenzyme $\mathrm{Q}_{10}$ serum levels [121], this could potentially explain reports of an inverse relationship between serum lipoprotein levels and PD risk [110]. Since lower serum cholesterol 
levels are associated with a decreased risk of MSA $[98,99]$ and serum cholesterol determines coenzyme $\mathrm{Q}_{10}$ levels [121] it could be inferred that altered cholesterol homeostasis in turn alters the amount of coenzyme $\mathrm{Q}_{10}$ present. As deficiencies in coenzyme $\mathrm{Q}_{10}$ are known to induce oxidative stress $[77,78]$, this then poses another mechanism by which peripheral lipid dyshomeostasis could contribute to the pathogenesis of MSA. This possibility is also in accordance with the finding that $C O Q 2$ mutations were more common in MSA patients with predominant cerebellar involvement [10], as a previous study has shown the cerebellum in both rats and humans contains the lowest concentration of coenzyme $\mathrm{Q}_{10}$ in the brain [122]. Hence, it appears the cerebellum may have heightened vulnerability to the damaging consequences of mutations in the COQ2 gene.

\section{Conclusions}

In conclusion $\alpha$-syn is a predominantly neuronal protein, which associates with lipid membranes and plays a role in synaptic vesicle function and turnover. In addition $\alpha$-syn has wider roles in brain lipid metabolism, which are likely to be important to both neuronal and glial cell function. The studies summarized above provide a guide for the interaction of lipid dyshomeostasis, altered membrane composition and $\alpha$-syn dysfunction. Oligodendrocytes are responsible for organising and maintaining the bulk of brain lipid in the form of the specialised myelin membrane. Myelin instability, potentially mediated by abnormalities of $\mathrm{ABCA} 8$ lipid transporter expression, may be an important precursor to $\alpha$-syn pathology in MSA, consistent with the unique oligodendrocyte focus of the disease. $\mathrm{ABC}$ transporters require ATP and functional mutations in $C O Q 2$ affecting coenzyme $\mathrm{Q}_{10}$ affect respiratory chain production of ATP. Together these deficits may contribute to the death and dysfunction of oligodendrocytes in MSA. Future studies should give due focus to the unique lipid-related processes underlying MSA pathology in contrast to the neuronal $\alpha$-synucleinopathies, especially energy production required for sphingolipid processing and myelin membrane integrity.

\section{Competing interests}

The authors declare that they have no competing interest.

\section{Authors' contributions}

WSK conceived and structured the review idea. JMB, JHW and WSK carried out the literature search and wrote the manuscript. WSK and GMH critically read and revised the manuscript. All authors read and approved the final manuscript.

\section{Acknowledgements}

This work was supported by a National Health and Medical Research Council of Australia (NHMRC) project grant (\#1022325). GMH is a NHMRC Senior Principal Research Fellow (\#630434).

Received: 3 February 2014 Accepted: 3 February 2014

Published: 7 February 2014

\section{References}

1. Wenning G, Tison F, Ben Shlomo Y, Daniel S, Quinn N: Multiple system atrophy: a review of 203 pathologically proven cases. Mov Disord 1997, 12(2):133-147.

2. Ozawa T, Okuizumi K, Ikeuchi T, Wakabayashi K, Takahashi H, Tsuji S: Analysis of the expression level of alpha-synuclein mRNA using postmortem brain samples from pathologically confirmed cases of multiple system atrophy. Acta Neuropathol 2001, 102(2):188-190.

3. Wenning G, Shlomo YB, Magalhaes M, Danie S, Quinn N: Clinical features and natural history of multiple system atrophy. Brain 1994, 117(4):835-845.

4. Schrag A, Wenning GK, Quinn N, Ben-Shlomo Y: Survival in multiple system atrophy. Mov Disord 2008, 23(2):294-296.

5. Papapetropoulos S, Tuchman A, Laufer D, Papatsoris AG, Papapetropoulos N, Mash DC: Causes of death in multiple system atrophy. $J$ Neurol Neurosurg Psychiatry 2007, 78(3):327-329.

6. Schrag A, Ben-Shlomo Y, Quinn N: Prevalence of progressive supranuclear palsy and multiple system atrophy: a cross-sectional study. Lancet 1999, 354(9192):1771-1775.

7. Bower JH, Maraganore DM, McDonnell SK, Rocca WA: Incidence of progressive supranuclear palsy and multiple system atrophy in Olmsted County, Minnesota, 1976 to 1990. Neurology 1997, 49(5):1284-1288.

8. Hara K, Momose Y, Tokiguchi S, Shimohata M, Terajima K, Onodera O, Kakita A, Yamada M, Takahashi H, Hirasawa M: Multiplex families with multiple system atrophy. Arch Neurol 2007, 64(4):545-551.

9. Soma H, Yabe I, Takei A, Fujiki N, Yanagihara T, Sasaki H: Heredity in multiple system atrophy. J Neurol Sci 2006, 240(1):107-110.

10. Multiple-System Atrophy Research C: Mutations in COQ2 in familial and sporadic multiple-system atrophy. New Engl J Med 2013, 369(3):233-244. doi:10.1056/NEJMoa1212115.

11. Stemberger S, Scholz SW, Singleton AB: Wenning GK (2011) Genetic players in multiple system atrophy: unfolding the nature of the beast. Neurobiol Aging 1924, 32(10):e1925-1914. doi:10.1016/j.neurobiolaging.2011.04.001.

12. Chrysostome V, Tison F, Yekhlef F, Sourgen C, Baldi I, Dartigues JF: Epidemiology of multiple system atrophy: a prevalence and pilot risk factor study in Aquitaine, France. Neuroepidemiology 2004, 23(4):201-208.

13. Seo JH, Yong SW, Song SK, Lee JE, Sohn YH, Lee PH: A case-control study of multiple system atrophy in Korean patients. Mov Disord 2010, 25(12):1953-1959.

14. Vanacore N, Bonifati V, Fabbrini G, Colosimo C, De Michele G, Marconi R, Stocchi F, Nicholl D, Bonuccelli U, De Mari M, Vieregge P, Meco G, Consortium E: Case-control study of multiple system atrophy. Mov Disord 2005, 20(2):158-163.

15. Vogt IR, Lees AJ, Evert BO, Klockgether T, Bonin M, Wüllner U: Transcriptional changes in multiple system atrophy and parkinson's disease putamen. Exp Neurol 2006, 199(2):465-478.

16. Nee LE, Gomez MR, Dambrosia J, Bale S, Eldridge R, Polinsky RJ: Environmental-occupational risk factors and familial associations in multiple system atrophy: A preliminary investigation. Clin Auton Res 1991, 1(1):9-13.

17. Papp MI, Kahn JE, Lantos PL: Glial cytoplasmic inclusions in the CNS of patients with multiple system atrophy (striatonigral degeneration, olivopontocerebellar atrophy and Shy-Drager syndrome). J Neurol Sci 1989, 94(1):79-100.

18. Fortin DL, Troyer MD, Nakamura K, Kubo S, Anthony MD, Edwards RH: Lipid rafts mediate the synaptic localization of a-synuclein. J Neurosci 2004, 24(30):6715-6723.

19. Jo E, McLaurin JA, Yip CM, St George-Hyslop P, Fraser PE: a-Synuclein membrane interactions and lipid specificity. J Biol Chem 2000, 275(44):34328-34334.

20. Abeliovich A, Schmitz Y, Farinas I, Choi-Lundberg D, Ho WH, Castillo PE, Shinsky N, Verdugo JM, Armanini M, Ryan A, Hynes M, Phillips $H$, Sulzer D, Rosenthal A: Mice lacking alpha-synuclein display functional deficits in the nigrostriatal dopamine system. Neuron 2000, 25(1):239-252.

21. Gai WP, Pountney DL, Power JHT, Li QX, Culvenor JG, McLean C, Jensen PH, Blumbergs PC: a-synuclein fibrils constitute the central core of oligodendroglial inclusion filaments in multiple system atrophy. Exp Neurol 2003, 181(1):68-78.

22. Michikawa M: Cholesterol paradox: is high total or low HDL cholesterol level a risk for Alzheimer's disease? J Neurosci Res 2003, 72(2):141-146.

23. Teunissen C, Lütjohann D, Von Bergmann K, Verhey F, Vreeling F, Wauters A, Bosmans $\mathrm{E}$, Bosma $\mathrm{H}$, van Boxtel M, Maes M: Combination of serum 
markers related to several mechanisms in Alzheimer's disease. Neurobiol Aging 2003, 24(7):893-902.

24. Baumann N, Pham-Dinh D: Biology of oligodendrocyte and myelin in the mammalian central nervous system. Physiol Rev 2001, 81(2):871-927.

25. Ravera S, Bartolucci M, Calzia D, Aluigi MG, Ramoino P, Morelli A, Panfoli I: Tricarboxylic acid cycle-sustained oxidative phosphorylation in isolated myelin vesicles. Biochimie 2013, 95(11):1991-1998. doi:10.1016/j. biochi.2013.07.003.

26. Wang JT, Medress ZA, Barres BA: Axon degeneration: molecular mechanisms of a self-destruction pathway. J Cell Biol 2012, 196(1):7-18 doi:10.1083/jcb.201108111.

27. Smith CM, Cooksey E, Duncan ID: Myelin loss does not lead to axonal degeneration in a long-lived model of chronic demyelination. J NeurosC 2013, 33(6):2718-2727. doi:10.1523/JNEUROSCI.4627-12.2013.

28. Song YJ, Lundvig DM, Huang Y, Gai WP, Blumbergs PC, Hojrup P, Otzen D, Halliday GM, Jensen PH: p25alpha relocalizes in oligodendroglia from myelin to cytoplasmic inclusions in multiple system atrophy. Am J Pathol 2007, 171(4):1291-1303.

29. Matsuo A, Akiguchi I, Lee GC, McGeer EG, McGeer PL, Kimura J: Myelin degeneration in multiple system atrophy detected by unique antibodies. Am J Pathol 1998, 153(3):735-744.

30. Lindersson E, Lundvig D, Petersen C, Madsen P, Nyengaard JR, Hojrup P, Moos T, Otzen D, Gai WP, Blumbergs PC, Jensen PH: p25alpha Stimulates alpha-synuclein aggregation and is co-localized with aggregated alpha-synuclein in alpha-synucleinopathies. J Biol Chem 2005, 280(7):5703-5715. doi:10.1074/jbc.M410409200

31. Kragh CL, Lund LB, Febbraro F, Hansen HD, Wei-Ping G, El-Agnaf O, Richter-Landsberg C, Jensen PH: alpha-synuclein aggregation and Ser-129 phosphorylation-dependent cell death in oligodendroglial cells. J Biol Chem 2009, 284(15):10211-10222.

32. Kovacs GG, Gelpi E, Lehotzky A, Hotberger R, Erdei A, Budka H, Ovadi J: The brain-specific protein TPPP/p25 in pathological protein deposits of neurodegenerative diseases. Acta Neuropathol 2007, 113(2):153-161.

33. Giasson Bl, Murray IV, Trojanowski JQ, Lee VM-Y: A hydrophobic stretch of 12 amino acid residues in the middle of a-synuclein is essential for filament assembly. J Biol Chem 2001, 276(4):2380-2386.

34. Conway KA, Harper JD, Lansbury PT Jr: Fibrils formed in vitro from a-synuclein and two mutant forms linked to Parkinson's disease are typical amyloid. Biochemistry 2000, 39(10):2552-2563.

35. Li J, Uversky VN, Fink AL: Effect of familial parkinson's disease point mutations $\mathrm{A} 30 \mathrm{P}$ and $\mathrm{A} 53 \mathrm{~T}$ on the structural properties, aggregation, and fibrillation of human a-synuclein. Biochemistry 2001, 40(38):11604-11613.

36. Conway KA, Lee S-J, Rochet J-C, Ding TT, Williamson RE, Lansbury PT: Acceleration of oligomerization, not fibrillization, is a shared property of both a-synuclein mutations linked to early-onset Parkinson's disease: implications for pathogenesis and therapy. Proc Natl Acad Sci 2000, 97(2):571-576.

37. Lashuel HA, Petre BM, Wall J, Simon M, Nowak RJ, Walz T, Lansbury PT Jr: a-synuclein, especially the parkinson's disease-associated mutants, forms pore-like annular and tubular protofibrils. J Mol Biol 2002, 322(5):1089-1102.

38. Goldberg MS, Lansbury PT Jr: Is there a cause-and-effect relationship between a-synuclein fibrillization and Parkinson's disease? Nat Cell Biol 2000, 2(7):E115-E119.

39. Davidson WS, Jonas A, Clayton DF, George JM: Stabilization of a-synuclein secondary structure upon binding to synthetic membranes. J Biol Chem 1998, 273(16):9443-9449.

40. Perrin RJ, Woods WS, Clayton DF, George JM: Exposure to long chain polyunsaturated fatty acids triggers rapid multimerization of synucleins. J Biol Chem 2001, 276(45):41958-41962.

41. Cole NB, Murphy DD, Grider T, Rueter S, Brasaemle D, Nussbaum RL: Lipid droplet binding and oligomerization properties of the parkinson's disease protein a-synuclein. J Bio/ Chem 2002, 277(8):6344-6352.

42. Lee HJ, Choi C, Lee SJ: Membrane-bound a-synuclein has a high aggregation propensity and the ability to seed the aggregation of the cytosolic form. J Biol Chem 2002, 277(1):671-678.

43. Decker $L$, Ffrench-Constant $C$ : Lipid rafts and integrin activation regulate oligodendrocyte survival. J Neurosci 2004, 24(15):3816-3825. 10.1523/JNEUROSCI.5725-03.2004

44. Pike LJ: Rafts defined: a report on the keystone symposium on lipid rafts and cell function. J Lipid Res 2006, 47(7):1597-1598.
45. Simons M, Krämer EM, Thiele C, Stoffel W, Trotter J: Assembly of myelin by association of proteolipid protein with cholesterol-and galactosylceramide-rich membrane domains. J Cell Biol 2000, 151(1):143-154.

46. Hanada K, Nishijima M, Akamatsu Y, Pagano RE: Both sphingolipids and cholesterol participate in the detergent insolubility of alkaline phosphatase, a glycosylphosphatidylinositol-anchored protein, in mammalian membranes. J Biol Chem 1995, 270(11):6254-6260.

47. Scheiffele $P$, Roth $M G$, Simons $K$ : Interaction of influenza virus haemagglutinin with sphingolipid-cholesterol membrane domains via its transmembrane domain. EMBO J 1997, 16(18):5501-5508. doi:10.1093/emboj/16.18.5501.

48. Jensen PH, Nielsen MS, Jakes R, Dotti CG, Goedert M: Binding of a-synuclein to brain vesicles is abolished by familial Parkinson's disease mutation. J Biol Chem 1998, 273(41):26292-26294.

49. Jo E, Fuller N, Rand RP, St George-Hyslop P, Fraser PE: Defective membrane interactions of familial parkinson's disease mutant $\mathrm{A} 30 \mathrm{P}$ a-synuclein. J Mol Biol 2002, 315(4):799-807

50. Scholz SW, Houlden H, Schulte C, Sharma M, Li A, Berg D, Melchers A, Paudel R, Gibbs JR, Simon-Sanchez J, Paisan-Ruiz C, Bras J, Ding J, Chen H, Traynor BJ, Arepalli S, Zonozi RR, Revesz T, Holton J, Wood N, Lees A, Oertel W, Wullner U, Goldwurm S, Pellecchia MT, Illig T, Riess O, Fernandez HH, Rodriguez RL, Okun MS, et al: SNCA variants are associated with increased risk for multiple system atrophy. Ann Neurol 2009, 65(5):610-614. doi:10.1002/ana.21685.

51. Maroteaux L, Campanelli JT, Scheller RH: Synuclein: a neuron-specific protein localized to the nucleus and presynaptic nerve terminal. J Neurosci Offic J Soc Neurosci 1988, 8(8):2804-2815.

52. Iwai A, Masliah E, Yoshimoto M, Ge N, Flanagan L, de Silva HA, Kittel A Saitoh T: The precursor protein of non-A beta component of Alzheimer's disease amyloid is a presynaptic protein of the central nervous system. Neuron 1995, 14(2):467-475.

53. Weinreb PH, Zhen W, Poon AW, Conway KA, Lansbury PT Jr: NACP, a protein implicated in alzheimer's disease and learning, is natively unfolded. Biochemistry 1996, 35(43):13709-13715.

54. McLean PJ, Kawamata H, Ribich S, Hyman BT: Membrane association and protein conformation of a-synuclein in intact neurons. J Biol Chem 2000, 275(12):8812-8816.

55. Sharon R, Goldberg MS, Bar-Josef I, Betensky RA, Shen J, Selkoe DJ: a-synuclein occurs in lipid-rich high molecular weight complexes, binds fatty acids, and shows homology to the fatty acid-binding proteins. Proc Natl Acad Sci 2001, 98(16):9110-9115.

56. Cabin DE, Shimazu K, Murphy D, Cole NB, Gottschalk W, Mcllwain KL, Orrison B, Chen A, Ellis CE, Paylor R: Synaptic vesicle depletion correlates with attenuated synaptic responses to prolonged repetitive stimulation in mice lacking a-synuclein. J Neurosci 2002, 22(20):8797-8807.

57. Jenco JM, Rawlingson A, Daniels B, Morris AJ: Regulation of phospholipase D2: selective inhibition of mammalian phospholipase $D$ isoenzymes by a-and $\beta$-synucleins. Biochemistry 1998, 37(14):4901-4909.

58. Payton JE, Perrin RJ, Woods WS, George JM: Structural determinants of PLD2 inhibition by a-synuclein. J Mol Biol 2004, 337(4):1001-1009.

59. Liscovitch M, Czarny M, Fiucci G, Tang X: Phospholipase D: molecular and cell biology of a novel gene family. Biochem J 2000, 345(Pt 3):401.

60. Narayanan V, Guo Y, Scarlata S: Fluorescence studies suggest a role for alpha-synuclein in the phosphatidylinositol lipid signaling pathway. Biochemistry 2005, 44(2):462-470. doi:10.1021/bi0487140.

61. Guo Y, Rosati B, Scarlata S: alpha-Synuclein increases the cellular level of phospholipase Cbeta1. Cell Signal 2012, 24(5):1109-1114 doi:10.1016/j.cellsig.2012.01.007

62. Castagnet PI, Golovko MY, Barcelo-Coblijn GC, Nussbaum RL, Murphy EJ: Fatty acid incorporation is decreased in astrocytes cultured from alpha-synuclein gene-ablated mice. J Neurochem 2005, 94(3):839-849. doi:10.1111/j.1471-4159.2005.03247.x

63. Golovko MY, Faergeman NJ, Cole NB, Castagnet PI, Nussbaum RL, Murphy EJ: a-synuclein gene deletion decreases brain palmitate uptake and alters the palmitate metabolism in the absence of a-synuclein palmitate binding. Biochemistry 2005, 44(23):8251-8259.

64. Golovko MY, Rosenberger TA, Færgeman NJ, Feddersen S, Cole NB, Pribill I, Berger J, Nussbaum RL, Murphy EJ: Acyl-CoA synthetase activity links wild-type but not mutant a-synuclein to brain arachidonate metabolism Biochemistry 2006, 45(22):6956-6966. 
65. Ellis CE, Murphy EJ, Mitchell DC, Golovko MY, Scaglia F, Barceló-Coblijn GC, Nussbaum RL: Mitochondrial lipid abnormality and electron transport chain impairment in mice lacking a-synuclein. Mol Cell Biol 2005, 25(22):10190-10201.

66. Gu M, Gash MT, Cooper JM, Wenning GK, Daniel SE, Quinn NP, Marsden CD, Schapira AH: Mitochondrial respiratory chain function in multiple system atrophy. Mov Disord 1997, 12(3):418-422. doi:10.1002/mds.870120323.

67. Stefanova N, Reindl M, Neumann M, Haass C, Poewe W, Kahle PJ, Wenning GK: Oxidative stress in transgenic mice with oligodendroglial a-synuclein overexpression replicates the characteristic neuropathology of multiple system atrophy. Am J Pathol 2005, 166(3):869-876.

68. Ubhi K, Lee PH, Adame A, Inglis C, Mante M, Rockenstein E, Stefanova N, Wenning GK, Masliah E: Mitochondrial inhibitor 3-nitroproprionic acid enhances oxidative modification of alpha-synuclein in a transgenic mouse model of multiple system atrophy. J Neurosci Res 2009, 87(12):2728-2739.

69. Duda JE, Giasson Bl, Gur TL, Montine TJ, Robertson D, Biaggioni I, Hurtig HI, Stern MB, Gollomp SM, Grossman M: Immunohistochemical and biochemical studies demonstrate a distinct profile of [alpha]-synuclein permutations in multiple system atrophy. I Neuropathol Exp Neurol 2000, 59(9):830.

70. Dickson D, Liu WK, Hardy J, Farrer M, Mehta N, Uitti R, Mark M, Zimmerman T, Golbe L, Sage J: Widespread alterations of a-synuclein in multiple system atrophy. Am J Pathol 1999, 155(4):1241-1251.

71. Pawlyk AC, Giasson Bl, Sampathu DM, Perez FA, Lim KL, Dawson VL, Dawson TM, Palmiter RD, Trojanowski JQ, Lee VMY: Novel monoclona antibodies demonstrate biochemical variation of brain parkin with age. J Biol Chem 2003, 278(48):48120-48128.

72. Tong J, Wong H, Guttman M, Ang LC, Forno LS, Shimadzu M, Rajput AH, Muenter MD, Kish SJ, Hornykiewicz O: Brain a-synuclein accumulation in multiple system atrophy, parkinson's disease and progressive supranuclear palsy: a comparative investigation. Brain 2010, 133(1):172-188.

73. Uryu K, Richter-Landsberg C, Welch W, Sun E, Goldbaum O, Norris EH, Pham CT, Yazawa I, Hilburger K, Micsenyi M: Convergence of heat shock protein 90 with ubiquitin in filamentous a-synuclein inclusions of a-synucleinopathies. Am J Pathol 2006, 168(3):947-961.

74. Tu P, Galvin JE, Baba M, Giasson B, Tomita T, Leight S, Nakajo S, Iwatsubo T, Trojanowski JQ, Lee VMY: Glial cytoplasmic inclusions in white matter oligodendrocytes of multiple system atrophy brains contain insoluble a-synuclein. Ann Neurol 1998, 44(3):415-422.

75. Quinzii C, Naini A, Salviati L, Trevisson E, Navas P, Dimauro S, Hirano M: A mutation in para-hydroxybenzoate-polyprenyl transferase $(\mathrm{COQ} 2)$ causes primary coenzyme Q10 deficiency. Am J Hum Genet 2006, 78(2):345-349. doi:10.1086/500092.

76. Turunen M, Olsson J, Dallner G: Metabolism and function of coenzyme Q. Biochim Biophys Acta 2004, 1660(1-2):171-199.

77. Quinzii CM, Lopez LC, Von-Moltke J, Naini A, Krishna S, Schuelke M, Salviati L, Navas P, DiMauro S, Hirano M: Respiratory chain dysfunction and oxidative stress correlate with severity of primary CoQ10 deficiency. FASEB J Offic Publ Fed Am Soc Exp Biol 2008, 22(6):1874-1885. doi:10.1096/fj.07-100149.

78. Quinzii CM, Lopez LC, Gilkerson RW, Dorado B, Coku J, Naini AB, Lagier-Tourenne C, Schuelke M, Salviati L, Carrozzo R, Santorelli F, Rahman S, Tazir M, Koenig M, DiMauro S, Hirano M: Reactive oxygen species, oxidative stress, and cell death correlate with level of CoQ10 deficiency. FASEB J Offic Publ Fed Am Soc Exp Biol 2010, 24(10):3733-3743. doi:10.1096/fj.09-152728.

79. Lamperti C, Naini A, Hirano M, De Vivo DC, Bertini E, Servidei S, Valeriani M, Lynch D, Banwell B, Berg M, Dubrovsky T, Chiriboga C, Angelini C, Pegoraro E, DiMauro S: Cerebellar ataxia and coenzyme Q10 deficiency. Neurology 2003, 60(7):1206-1208

80. Artuch R, Brea-Calvo G, Briones P, Aracil A, Galvan M, Espinos C, Corral J, Volpini V, Ribes A, Andreu AL, Palau F, Sanchez-Alcazar JA, Navas P, Pineda M: Cerebellar ataxia with coenzyme Q10 deficiency: diagnosis and follow-up after coenzyme Q10 supplementation. J Neurol Sci 2006, 246(1-2):153-158. doi:10.1016/j.jns.2006.01.021.

81. Funfschilling U, Supplie LM, Mahad D, Boretius S, Saab AS, Edgar J, Brinkmann BG, Kassmann CM, Tzvetanova ID, Mobius W, Diaz F, Meijer D, Suter U, Hamprecht B, Sereda MW, Moraes CT, Frahm J, Goebbels S, Nave KA: Glycolytic oligodendrocytes maintain myelin and long-term axonal integrity. Nature 2012, 485(7399):517-521. doi:10.1038/nature11007.
82. Hung LW, Wang IX, Nikaido K, Liu PQ, Ames GF, Kim SH: Crystal structure of the ATP-binding subunit of an ABC transporter. Nature 1998, 396(6712):703-707. doi:10.1038/25393

83. Klein I, Sarkadi B, Varadi A: An inventory of the human ABC proteins. Biochim Biophys Acta 1999, 1461(2):237-262.

84. Kaminski WE, Piehler A, Wenzel JJ: ABC A-subfamily transporters: structure, function and disease. Bioch Biophy Acta (BBA)-Mol Basis Dis 2006, 1762(5):510-524

85. Kim WS, Weickert CS, Garner B: Role of ATP-binding cassette transporters in brain lipid transport and neurological disease. J Neurochem 2008, 104(5):1145-1166.

86. Kim WS, Hsiao JH, Bhatia S, Glaros EN, Don AS, Tsuruoka S, Shannon Weickert C, Halliday GM: ABCA8 stimulates sphingomyelin production in oligodendrocytes. Biochem J 2013, 452(3):401-410. doi:10.1042/BJ20121764.

87. Benes FM, Turtle M, Khan Y, Farol P: Myelination of a key relay zone in the hippocampal formation occurs in the human brain during childhood, adolescence, and adulthood. Arch Gen Psychiatry 1994, 51(6):477-484.

88. Miller DJ, Duka T, Stimpson CD, Schapiro SJ, Baze WB, McArthur MJ, Fobbs AJ, Sousa AMM, Šestan N, Wildman DE: Prolonged myelination in human neocortical evolution. Proc Nat/ Acad Sci U S A 2012, 109(41):16480-16485.

89. Barenholz $Y$, Thompson $\mathrm{T}$ : Sphingomyelins in bilayers and biological membranes. Biochimica et biophysica acta (BBA)-reviews on. Biomembranes 1980, 604:129-158.

90. Kalvodova L, Kahya N, Schwille P, Ehehalt R, Verkade P, Drechsel D, Simons K: Lipids as modulators of proteolytic activity of BACE involvement of cholesterol, glycosphingolipids, and anionic phospholipids in vitro. $\mathrm{J}$ Biol Chem 2005, 280(44):36815-36823.

91. Mathias S, Pena L, Kolesnick R: Signal transduction of stress via ceramide. Biochem J 1998, 335:465-480.

92. Brady RO, Kanfer JN, Mock MB, Fredrickson DS: The metabolism of sphingomyelin. II. Evidence of an enzymatic deficiency in Niemann-Pick diseae. Proc Natl Acad Sci U S A 1966, 55(2):366-369.

93. Bleasel JM, Hsiao JT, Halliday GM, Kim WS: Increased expression of ABCA8 in multiple system atrophy brain is associated with changes in pathogenic proteins. J Parkinson's Dis 2013. published online 24 June 2013.

94. Jin H, Ishikawa K, Tsunemi T, Ishiguro T, Amino T, Mizusawa H: Analyses of copy number and mRNA expression level of the alpha-synuclein gene in multiple system atrophy. J Med Dent Sci 2008, 55(1):145-153.

95. Langerveld AJ, Mihalko D, DeLong C, Walburn J, Ide CF: Gene expression changes in postmortem tissue from the rostral pons of multiple system atrophy patients. Mov Disord 2007, 22(6):766-777.

96. Miller D, Johnson J, Solano S, Hollingsworth Z, Standaert D, Young A: Absence of a-synuclein mRNA expression in normal and multiple system atrophy oligodendroglia. J Neural Transm 2005, 112(12):1613-1624.

97. Ozawa T: Morphological substrate of autonomic failure and neurohormonal dysfunction in multiple system atrophy: impact on determining phenotype spectrum. Acta Neuropathol 2007, 114(3):201-211.

98. Lee PH, Lim TS, Shin HW, Yong SW, Nam HS, Sohn YH: Serum cholesterol levels and the risk of multiple system atrophy: a case-control study. Movement Disorders 2009, 24(5):752-758.

99. Cao B, Guo X, Chen K, Song W, Huang R, Wei QQ, Zhao B, Shang HF: Serum lipid levels are associated with the prevalence but not with the disease progression of multiple system atrophy in a Chinese population. Neurol Res. 10.1179/1743132813Y.0000000277.

100. Vidal JS, Vidailhet M, Elbaz A, Derkinderen P, Tzourio C, Alperovitch A: Risk factors of multiple system atrophy: a case-control study in French patients. Mov Disord 2008, 23(6):797-803.

101. de Lau LML, Koudstaal PJ, Hofman A, Breteler MMB: Serum cholesterol levels and the risk of Parkinson's disease. Am J Epidemiol 2006, 164(10):998-1002.

102. Simon KC, Chen $H$, Schwarzschild M, Ascherio A: Hypertension, hypercholesterolemia, diabetes, and risk of parkinson disease. Neurology 2007, 69(17):1688-1695.

103. Scigliano G, Musicco M, Soliveri P, Piccolo I, Ronchetti G, Girotti F: Reduced risk factors for vascular disorders in parkinson disease patients a case-control study. Stroke 2006, 37(5):1184-1188.

104. Huang X, Chen H, Miller WC, Mailman RB, Woodard JL, Chen PC, Xiang D, Murrow RW, Wang YZ, Poole C: Lower low-density lipoprotein cholesterol levels are associated with parkinson's disease. Mov Disord 2007, 22(3):377-381.

105. Hu G, Antikainen R, Jousilahti P, Kivipelto M, Tuomilehto J: Total cholesterol and the risk of parkinson disease. Neurology 2008, 70(21):1972-1979. 
106. Grandinetti A, Morens DM, Reed D, MacEachern D: Prospective study of cigarette smoking and the risk of developing idiopathic Parkinson's disease. Am J Epidemiol 1994, 139(12):1129-1138.

107. Johnson C, Gorell J, Rybicki B, Sanders K, Peterson E: Adult nutrient intake as a risk factor for Parkinson's disease. Int J Epidemiol 1999, 28(6):1102-1109.

108. Logroscino G, Marder K, Cote L, Tang MX, Shea S, Mayeux R: Dietary lipids and antioxidants in Parkinson's disease: a population-based, case-control study. Ann Neurol 1996, 39(1):89-94

109. Anderson C, Checkoway H, Franklin GM, Beresford S, Smith-Weller T, Swanson PD: Dietary factors in parkinson's disease: the role of food groups and specific foods. Mov Disord 1999, 14(1):21-27.

110. de Lau L, Bornebroek M, Witteman J, Hofman A, Koudstaal P, Breteler M: Dietary fatty acids and the risk of parkinson disease the Rotterdam Study. Neurology 2005, 64(12):2040-2045.

111. Powers KM, Smith-Weller T, Franklin GM, Longstreth W Jr, Swanson PD, Checkoway H: Dietary fats, cholesterol and iron as risk factors for parkinson's disease. Parkinsonism Relat Disord 2009, 15(1):47-52.

112. Ross GW, White LR, Sanderson WT, Burchfiel CM, Kashon M, Sharp DS, Masaki KH, Curb JD, Petrovitch H: Environmental, life-style, and physical precursors of clinical parkinson's disease: recent findings from the Honolulu-Asia aging study. J Neurol 2003, 250(3):iii30-iii39.

113. Chen H, Zhang SM, Hernán MA, Willett WC, Ascherio A: Dietary intakes of fat and risk of parkinson's disease. Am J Epidemiol 2003, 157(11):1007-1014

114. Gudala K, Bansal D, Muthyala H: Role of serum cholesterol in Parkinson's disease: a meta-analysis of evidence. J Parkinson's Dis 2013, 3(3):363-370. doi:10.3233/JPD-130196.

115. Björkhem I, Meaney S: Brain cholesterol: long secret life behind a barrier. Arterioscler Thromb Vasc Biol 2004, 24(5):806-815.

116. Björkhem I, Lütjohann D, Diczfalusy U, Ståhle L, Ahlborg G, Wahren J: Cholesterol homeostasis in human brain: turnover of 24S-hydroxycholesterol and evidence for a cerebral origin of most of this oxysterol in the circulation. J Lipid Res 1998, 39(8):1594-1600.

117. Heverin M, Meaney S, Lütjohann D, Diczfalusy U, Wahren J, Björkhem I: Crossing the barrier: net flux of 27-hydroxycholesterol into the human brain. J Lipid Res 2005, 46(5):1047-1052.

118. Bosco DA, Fowler DM, Zhang Q, Nieva J, Powers ET, Wentworth P. Lerner RA Kelly JW: Elevated levels of oxidized cholesterol metabolites in Lewy body disease brains accelerate a-synuclein fibrilization. Nat Chem Biol 2006, 2(5):249-253.

119. Matthews RT, Yang L, Browne S, Baik M, Beal MF: Coenzyme Q10 administration increases brain mitochondrial concentrations and exerts neuroprotective effects. Proc Natl Acad Sci 1998, 95(15):8892-8897.

120. Shults CW, Oakes D, Kieburtz K, Beal MF, Haas R, Plumb S, Juncos JL, Nutt J, Shoulson I, Carter J: Effects of coenzyme Q10 in early parkinson disease: evidence of slowing of the functional decline. Arch Neurol 2002, 59(10):1541

121. Kaikkonen J, Nyyssonen K, Tuomainen TP, Ristonmaa U, Salonen JT: Determinants of plasma coenzyme Q10 in humans. FEBS Lett 1999, 443(2):163-166.

122. Naini A, Lewis VJ, Hirano M, DiMauro S: Primary coenzyme Q10 deficiency and the brain. Biofactors 2003, 18(1-4):145-152.

\section{doi:10.1186/2051-5960-2-15}

Cite this article as: Bleasel et al:: Lipid dysfunction and pathogenesis of multiple system atrophy. Acta Neuropathologica Communications 2014 2:15.

\section{Submit your next manuscript to BioMed Central and take full advantage of:}

- Convenient online submission

- Thorough peer review

- No space constraints or color figure charges

- Immediate publication on acceptance

- Inclusion in PubMed, CAS, Scopus and Google Scholar

- Research which is freely available for redistribution 